\title{
FORECASTING EVALUATION SAFETY MOTOR ROADS BY ESTIMATING SOCIO-ECONOMIC LOSSES FROM ROAD ACCIDENTS
}

\section{ПРОГНОЗУВАННЯ ОЦІККИ БЕЗПЕКИ АВТОМОБІЛЬНИХ ДОРІГ ЧЕРЕЗ РОЗРАХУНОК СОЦІАЛЬНО-ЕКОНОМІЧНИХ ВТРАТ ВІД ДОРОЖНЬО-ТРАНСПОРТНИХ ПРИГОД}

\author{
Stasiuk Bohdan \\ M.P. Shulgin State Road Research Institute State Enterprise \\ ORCID: https://orcid.org/0000-0003-2504-6577 \\ Стасюк Богдан Олександрович \\ начальник \\ Центру Державного підприємства \\ «Державний дорожній науково-дослідний інститут \\ імені М.П. Шульгіна»
}

\begin{abstract}
Road safety is a major factor in the economic growth of any country. When complying with all regulatory requirements for safety you can achieve "zero" deaths on the roads, in turn allows the efficient use of budgetary financial resources for other needs. In the conditions of constant growth of the number of vehicles on the highways of Ukraine, without proper development of the infrastructure the probability of accidents on the roads will increase. According to world statistics, every year road accidents kill tens of thousands and injure hundreds of thousands of people. Each traffic accident entails significant socio-economic losses, which depend exponentially on the severity of injuries or the presence of casualties. Thus, the annual amount of socio-economic losses from road accidents reflects the result of economic assessment of road safety. The object of the study is evaluation safety motor roads by the amount of socio-economic losses cased by road accidents in Ukraine and European countries. The purpose of the work is to calculate the approximate forecast of socio-economic losses in Ukraine and European countries until 2025 and to assess the effectiveness of investment in projects to improve road safety. Research methods - analysis of statistical data, forecasting of socio-economic losses on the basis of extrapolation of trends with the determination of the parameters of the quadratic equation by determinant method, comparison of the actual savings from reducing the losses from road accidents, calculation of economic efficiency of measures to improve road safety. The article presents the calculation of socio-economic losses from road accidents with the subsequent forecast of these costs in the 5-year perspective, as well as the evaluation of the effectiveness of investment in measures to improve road safety. It has been confirmed that the financing of road projects to improve road safety provides a significant economic benefit to the national economies of the European Union and Ukraine. The results of the work can be used in the investment process and in the preparation of a feasibility study of road projects.
\end{abstract}

Keywords: evaluation, safety, motor roads, road accidents, efficiency, losses, forecast.

Безпека на автомобільних дорогах - головний чинник економічного зростання будь-якої країни. За дотримання усіх нормативних вимог з безпеки можливо досягти «нульової» смертності на дорогах, що в свою чергу дозволяє есрективно використовувати бюджетні фрінансові ресурси на інші потреби. В умовах постійного зростання кількості транспортних засобів на автомобільних дорогах України, без належного розвитку інфрраструктури буде зростати ймовірність виникнення аварійних ситуацій на дорогах. Згідно світової статистики щороку дорожньо-транспортні пригоди стають причиною загибелі десятків тисяч і отримання травм сотнями тисяч людей. Кожна дорожньо-транспортна пригода несе за собою суттєві соціально-економічні втрати, які експоненціально залежать від тяжкості травм або наявності загиблих. Таким чином, річний розмір соціально-економічних втрат від дорожньо-транспортних пригод відображає результат економічного оцінювання безпеки автомобільних доріг. Об'єкт дослідження - оцінювання безпеки автомобільних доріг через визначення розміру соціально-економічних втрат від дорожньо-транспортних пригод в Україні та країнах Європи. Мета роботи - розрахувати орієнтовний прогноз соціально-економічних втрат в Україні та країнах Європи до 2025 року та оцінити ефективність інвестицій в проекти з підвищення безпеки дорожнього руху. Методи до- 
слідження - аналіз статистичних даних, прогнозування соціально-економічних втрат на основі екстраполяції трендів з визначенням параметрів квадратичного рівняння за методом детермінантів, порівняння фрактичної економії від зменшення втрат від дорожньо-транспортних пригод, розрахунок економічної ефрективності заходів з підвищення безпеки дорожнього руху. У статті представлено розрахунок соціально-економічних втрат від дорожньо-транспортних пригод з подальшим прогнозом цих витрат у 5-річній перспективі, а також оцінка ефективності інвестицій в заходи з підвищення безпеки дорожнього руху. Отримано підтвердження того, що фрінансування дорожніх проектів з підвищення безпеки руху дозволяє отримати значний економічний ефект для національної економіки країн Європейського Союзу та України. Результати роботи можуть бути використані під час інвестиційного процесу та при підготовці техніко-економічного обґрунтування дорожніх проектів.

Ключові слова: розрахунок, безпека, автомобільні дороги, дорожньо-транспортні пригоди, ефективність, втрати, прогноз.

Безопасность на автомобильных дорогах - главный фрактор экономического роста любой страны. При соблюдении всех нормативных требований по безопасности можно достичь «нулевой» смертности на дорогах, в свою очередь позволяет эффективно использовать бюджетные фринансовые ресурсы на другие нужды. В условиях постоянного роста количества транспортных средств на автомобильных дорогах Украины, без надлежащего развития инфраструктуры будет расти вероятность возникновения аварийных ситуаций на дорогах. Согласно мировой статистике ежегодно дорожно-транспортные происшествия становятся причиной гибели десятков тысяч и получения травм сотнями тысяч человек. Каждое дорожно-транспортное происшествие влечет за собой существенные социально-экономические потери, которые экспоненциально зависят от тяжести травм или наличии погибших. Таким образом, годовой размер социально-экономических потерь от дорожно-транспортных происшествий отражает результат экономической оценки безопасности автомобильных дорог. Объект исследования - оценка безопасности автомобильных дорог путем определения размера социально-экономических потерь от дорожно-транспортных происшествий в Украине и странах Европы. Цель работы - рассчитать ориентировочный прогноз социально-экономических потерь в Украине и странах Европы до 2025 года и оценить эффрективность инвестиций в проекты по повышению безопасности дорожного движения. Методы исследования - анализ статистических данных, прогнозирование социально-экономических потерь на основе экстраполяции трендов с определением параметров квадратичного уравнения методом детерминантов, сравнение фрактической экономии от снижения потерь от дорожно-транспортных происшествий, расчет экономической эффективности мероприятий по повышению безопасности дорожного движения. В статье представлены расчет социально-экономических потерь от дорожно-транспортных происшествий с последующим прогнозом этих расходов в 5-и летней перспективе, а также оценка эффективности инвестиций в мероприятия по повышению безопасности дорожного движения. Получено подтверждение того, что фринансирование дорожных проектов по повышению безопасности движения позволяет получить значительный экономический эффрект для национальной экономики стран Европейского Союза и Украины. Результаты работы могут быть использованы в ходе инвестиционного процесса и при подготовке техникоэкономического обоснования дорожных проектов.

Ключевые слова: расчет, безопасность, автомобильные дороги, дорожно-транспортные происшествия, эфрфективность, потери, прогноз.

Formulation of the problem. Road safety is a major factor in the economic growth of any country. When complying with all regulatory requirements for safety you can achieve "zero" deaths on the roads, in turn allows the efficient use of budgetary financial resources for other needs.

In the conditions of constant growth of the number of vehicles on the highways of Ukraine, without proper development of the infrastructure the probability of accidents on the roads will increase. According to world statistics, every year road accidents kill tens of thousands and injure hundreds of thousands of people.

Each traffic accident entails significant socio-economic losses, which depend exponentially on the severity of injuries or the presence of casualties. Thus, the annual amount of socio-economic losses from road accidents reflects the result of economic assessment of road safety.
An analysis of recent research and publications. Research in the field of the content of the concept of losses from road accidents has been reflected in the works of such scientists as N.M. Abramova, A.O. Bezugliy, Yu.P. Bytiak, B.T. Belous, I.M. Volkov, V.K. Gizhevsky, O.V. Dolzhenkova, I.P. Yemets, T.V. Katruk, V.O. Pavlenko, A.A. Sotnikova, K.V. Uvarova and V.P. Chizhevsky [1]. Despite the significance of the results obtained in the research, the question of the scope of the indicator of socio-economic losses from traffic accidents as a result of road safety assessment is rather uncertain.

Setting objectives. The object of the study is evaluation safety motor roads by the amount of socio-economic losses cased by road accidents in Ukraine and European countries.

The purpose of the work is to calculate the approximate forecast of socio-economic losses 
in Ukraine and European countries until 2025 and to assess the effectiveness of investment in projects to improve road safety.

\section{The main research material.}

1 Calculation of socio-economic losses from road accidents

To calculate the socio-economic losses caused by road accidents we will use the methodologies described in [1-4], namely, the calculation using data on the gross domestic product (GDP), the number of deaths in road accidents, the number of employed (economically active) population and a sustainable safety index (5.55).

\subsection{Initial data}

As thel data, statistical information for the main countries of the European Union and Ukraine were analyzed and selected from [5-9]. Let's consider separately the sets of initial data on GDP, the number of employed (economically active) population and the number of deaths from road accidents.

\subsubsection{Gross Domestic Product}

Using annual data from [5-6] for Ukraine and quarterly data from [7] for the main countries of the European Union, we obtained indicators of gross domestic product from 2009 to 2018 that are presented in Table 1. Given the absence of all necessary data in statistical databases, the initial data for these last 10 years will be the basis for further calculations.

Number of employed (economically active) population

Using annual data from [5] for Ukraine and quarterly data from [8] for the main European Union countries, we obtained the number of employed population from 2009 to 2018 presented in Table 2.

\subsubsection{Number of deaths in road accidents}

Using the accumulated annual statistical data from the Road Safety Department of the National Police of Ukraine contained in the electronic branch database of accounting and analysis of road accidents developed by "DerzhdorNDI" SE for Ukraine and the data from [9] for European countries, we obtained the number of deaths in road accidents, from 2009 to 2018 presented in Table 3.

1.2 Mathematical apparatus for calculating socio-economic losses from road accidents

The amount of social and economic losses caused by road traffic accidents is estimated on the basis of [10] and includes the calculation of direct and indirect social and economic losses.

Direct expenditures include losses of owners of rolling stock of motor transport, losses of road maintenance services in connection with elimination of consequences of road accidents and the losses of shippers, expenditures of National Police and legal authorities related to investigation of road accidents, expenditures of medical institutions for treatment of victims, expenditures of enterprises, which employees became victims of accidents (payment of bulletins, financial aid), expenditures of state social security bodies (pensions) and insurance payments.

Indirect losses include losses to the national economy as a result of temporary or complete withdrawal of a person from the sphere of material production, violation of production ties and moral losses received.

Losses from the death and injury of people constitute the largest part of losses from road accidents and include the following socio-economic indicators: economic losses due to the withdrawal of a person from the sphere of production; socio-economic losses of the state in payment of disability and survivor pensions, as well as payment for treatment in hospitals and temporary disability; socio-economic losses due to the death of children.

To assess the losses, the method of total income is used, which consists in a monetary assessment of the economic utility that society receives from the production processes in which a person is involved. That is, human labor is considered as a component of the state income received from the production and socio-economic activities of citizens.

According to [4], the amount of socio-economic losses from road accidents can be determined by "classical method" using 30 mathematical formulas of varying complexity and 57 variables as input data. Also, it is possible to calculate an approximate amount of losses based on the safety index. The error between the calculation by the "classical method" and using the safety index is less than $10 \%$, which is acceptable and will be used in further research in the conditions of limited detailed input data and in compliance with the purpose of the study.

Taking into account [4], the approximate amount of socio-economic losses from road accidents in this study is calculated on the basis of the following indicators: total number of deaths, the number of employed (economically active) population, the amount of GDP in actual prices and a sustainable safety index $(5,55)$, taking into account the formula (1):

$$
L_{\text {accidents }}=\frac{G D P}{P} \cdot \frac{V}{i_{\text {safety }}}
$$

$L_{\text {accidents }}$ - socio-economic losses from road accidents in monetary terms; 
Table 1

Gross Domestic Product for countries of the European Union and Ukraine from 2009 to 2018

\begin{tabular}{|c|c|c|c|c|c|c|c|c|c|c|}
\hline \multirow{2}{*}{ Country* } & \multicolumn{10}{|c|}{ GDP, billion euro } \\
\hline & 2009 & 2010 & 2011 & 2012 & 2013 & 2014 & 2015 & 2016 & 2017 & 2018 \\
\hline BEL & 346,5 & 363,1 & 376,0 & 386,2 & 392,9 & 403,0 & 416,7 & 430,1 & 445,0 & 460,4 \\
\hline BGR & 37,4 & 38,1 & 41,3 & 42,0 & 41,9 & 42,9 & 45,7 & 48,6 & 52,3 & 56,1 \\
\hline CZE & 149,7 & 158,0 & 165,2 & 162,6 & 159,4 & 157,8 & 169,6 & 177,4 & 194,4 & 210,9 \\
\hline DNK & 231,3 & 243,2 & 247,9 & 254,6 & 258,7 & 265,8 & 273,0 & 283,1 & 294,8 & 302,4 \\
\hline DEU & 2445,7 & 2564,4 & 2693,6 & 2745,3 & 2811,4 & 2927,4 & 3026,2 & 3134,7 & 3259,9 & 3356,4 \\
\hline EST & 14,2 & 14,9 & 16,8 & 18,1 & 19,0 & 20,2 & 20,8 & 21,9 & 23,9 & 25,9 \\
\hline IRL & 9,8 & 167,7 & 171,0 & 175,1 & 179,6 & 195,1 & 262,9 & 270,8 & 300,4 & 327,0 \\
\hline GRC & 37,5 & 4,1 & 203,3 & 188,4 & 179,6 & 177,3 & & 174,2 & 177,2 & 179,7 \\
\hline ESP & 1069,3 & 1072,7 & 1063,8 & 1031,1 & 1020,3 & 1032,2 & 1077,6 & 13,8 & 1161,9 & 1204,2 \\
\hline FRA & 1936,4 & 1995,3 & 2058,4 & 2088,8 & 2117,2 & 2149,8 & 2198,4 & 2234,1 & 2297,2 & 2360,7 \\
\hline HRV & 45,1 & 45,2 & 44,9 & 44,0 & 43,8 & 43,4 & 44,6 & 46,6 & 49,2 & 52,0 \\
\hline ITA & 1577,3 & 1611,3 & 1648,8 & 1624,4 & 1612,8 & 1627,4 & 1655,4 & 1695,8 & \begin{tabular}{|l|}
1736,6 \\
\end{tabular} & 1771,1 \\
\hline HUN & 94,6 & 99,5 & 102,0 & 100,2 & 102,0 & 106,1 & 112,7 & 6,2 & 126,9 & 135,8 \\
\hline MLT & 3 & 8 & 6,9 & & 7,9 & 8 & 0,0 & 0,6 & 1,7 & 12,5 \\
\hline NLD & 624,8 & 639,2 & 650,4 & 653,0 & 660,5 & 671,6 & 0,0 & 8,3 & 38,1 & 74,0 \\
\hline AUT & 8,0 & & 310,1 & 3,7 & 323,9 & 3,1 & 344,3 & 7,6 & 9,3 & 385,4 \\
\hline $\mathrm{POL}$ & 7,7 & 2,3 & 379,5 & 388,2 & 392,4 & 408,9 & 430,3 & 427,0 & 467,7 & 497,6 \\
\hline PRT & 175,4 & 179,6 & 176,1 & 168,3 & 170,5 & 173,1 & 179,7 & 186,5 & 95,9 & 205,2 \\
\hline ROU & 125,2 & 125,2 & 131,7 & 132,4 & 143,6 & 150,8 & 160,2 & 170,1 & 187,5 & 204,5 \\
\hline SVN & 36,3 & 36,4 & 37,1 & 36,3 & 36,5 & 37,6 & 38,9 & 40,4 & 43,0 & 45,9 \\
\hline SVK & 64,1 & 68,2 & & & 74,4 & 76,3 & 79,8 & 81,1 & 84,5 & 89,5 \\
\hline FIN & 181,7 & 188,1 & 198,0 & 201,0 & 204,3 & 206,9 & 211,4 & 217,5 & 226,3 & 233,6 \\
\hline SWE & 314,7 & 375,2 & 412,9 & 430,0 & 441,9 & 438,9 & 455,6 & 466,3 & 479,8 & 470,7 \\
\hline GBR & 1738,3 & 1872,6 & 1913,6 & 2111,9 & 2096,7 & 2311,5 & 2645,0 & 2440,6 & \begin{tabular}{|l|}
2360,6 \\
\end{tabular} & 2421,1 \\
\hline ISL & 9,4 & 10,4 & 10,9 & 11,5 & 12,1 & 13,5 & 15,8 & 18,9 & 21,9 & 22,3 \\
\hline NOR & 278,5 & 323,7 & 358,4 & 396,6 & 393,8 & 375,9 & 348,3 & 333,7 & 353,3 & 370,3 \\
\hline $\mathrm{CHE}$ & 402,2 & 456,7 & 520,8 & 538,5 & 536,7 & 554,0 & 633,0 & 628,8 & 624,2 & 623,2 \\
\hline UKR & 87,1 & 99,3 & 123,4 & 126,6 & 142,7 & 149,5 & 126,3 & 98,6 & 105,5 & 118,6 \\
\hline
\end{tabular}

Source: compiled by the author, taking into account annual data from [5-7]

Note to Tables 1-3 - interpretation of country name abbreviations
BEL - Belgium
BGR - Bulgaria
CZE - Czechia
DNK - Denmark
DEU - Germany
HUN - Hungary
MLT - Malta
NLD - Netherlands
AUT - Austria
POL - Poland
EST - Estonia
PRT - Portugal
IRL - Ireland
ROU - Romania
GRC - Greece
SVN - Slovenia
ESP - Spain
SVK - Slovakia
FRA - France
FIN - Finland
HRV - Croatia
SWE - Sweden
ITA - Italy
CYP - Cyprus
GBR - United Kingdom
LVA - Latvia
ISL - Iceland
LTU - Lithuania
NOR - Norway
LUX - Luxembourg
CHE - Switzerland
UKR - Ukraine 
Table 2

Number of employed population for countries of the European Union and Ukraine from 2009 to 2018

\begin{tabular}{|c|c|c|c|c|c|c|c|c|c|c|}
\hline \multirow{2}{*}{ Country* } & \multicolumn{10}{|c|}{ Population, million persons } \\
\hline & 2009 & 2010 & 2011 & 2012 & 2013 & 2014 & 2015 & 2016 & 2017 & 2018 \\
\hline BEL & 18,2 & 18,3 & 18,5 & 18,6 & 18,6 & 18,6 & 18,8 & 19,0 & 19,3 & 19,6 \\
\hline BGR & 15,0 & 14,4 & 14,1 & 13,7 & 13,7 & 13,7 & 13,8 & 13,9 & 14,1 & 14,1 \\
\hline CZE & 20,0 & 19,9 & 20,0 & 20,0 & 20,2 & 20,4 & 20,7 & 21,0 & 21,3 & 21,5 \\
\hline DNK & 11,3 & 11,0 & 11,0 & 10,9 & 10,9 & 11,0 & 11,2 & 11,4 & 11,5 & 11,7 \\
\hline DEU & 163,4 & 164,0 & 166,0 & 167,9 & 169,1 & 170,6 & 172,1 & 174,2 & 176,6 & 178,9 \\
\hline EST & 2,4 & 2,3 & 2,4 & 2,5 & 2,5 & 2,5 & 2,6 & 2,6 & 2,6 & 2,7 \\
\hline IRL & 7,8 & 7,5 & 7,4 & 7,4 & 7,6 & 7,8 & 8,1 & 8,3 & 8,6 & 8,9 \\
\hline GRC & 19,3 & 18,8 & 17,9 & 17,2 & 17,1 & 17,7 & 17,1 & 17,7 & 17,6 & 17,8 \\
\hline ESP & 79,4 & 78,1 & 76,1 & 73,1 & 71,4 & 72,1 & 74,2 & 75,8 & 77,8 & 79,5 \\
\hline FRA & 108,7 & 108,9 & 109,7 & 110,1 & 110,3 & 111,0 & 111,2 & 112,0 & 113,3 & 114,5 \\
\hline HRV & 7,1 & 6,8 & 6,5 & 6,3 & 6,1 & 6,3 & 6,4 & 6,4 & 6,5 & 6,7 \\
\hline ITA & 98,3 & 97,7 & 97,9 & 97,2 & 95,7 & 95,5 & 96,1 & 97,6 & 98,5 & 99,4 \\
\hline CYP & 1,6 & 1,6 & 1,6 & 1,6 & 1,5 & 1,5 & 1,5 & 1,5 & 1,6 & 1,7 \\
\hline LVA & 3,6 & 3,4 & 3,5 & 3,5 & 3,6 & 3,6 & 3,6 & 3,6 & 3,6 & 3,7 \\
\hline LTU & 5,3 & 5,0 & 5,0 & 5,1 & 5,2 & 5,3 & 5,3 & 5,5 & 5,4 & 5,5 \\
\hline LUX & 0,9 & 0,9 & 0,9 & 0,9 & 0,9 & 1,0 & 1,0 & 1,0 & 1,0 & 1,1 \\
\hline HUN & 15,0 & 14,9 & 15,0 & 15,3 & 15,6 & 16,4 & 16,8 & 17,4 & 17,7 & 17,9 \\
\hline MLT & 0,6 & 0,7 & 0,7 & 0,7 & 0,7 & 0,8 & 0,8 & 0,8 & 0,9 & 0,9 \\
\hline NLD & 34,8 & 34,6 & 34,9 & 34,8 & 34,4 & 34,4 & 34,7 & 35,2 & 36,0 & 36,9 \\
\hline AUT & 16,2 & 16,3 & 16,5 & 16,6 & 16,6 & 16,7 & 16,8 & 17,0 & 17,2 & 17,5 \\
\hline POL & 63,5 & 61,9 & 62,3 & 62,4 & 62,3 & 63,4 & 64,3 & 64,8 & 65,7 & 65,9 \\
\hline PRT & 19,9 & 19,7 & 19,2 & 18,4 & 17,9 & 18,2 & 18,4 & 18,7 & 19,3 & 19,8 \\
\hline ROU & 36,9 & 35,8 & 35,0 & 35,3 & 34,9 & 35,1 & 34,7 & 34,3 & 35,2 & 35,3 \\
\hline SVN & 3,9 & 3,8 & 3,8 & 3,8 & 3,7 & 3,7 & 3,8 & 3,9 & 4,0 & 4,1 \\
\hline SVK & 9,5 & 9,3 & 9,3 & 9,3 & 9,3 & 9,5 & 9,7 & 10,0 & 10,1 & 10,3 \\
\hline FIN & 10,0 & 10,0 & 10,1 & 10,2 & 10,1 & 10,1 & 10,1 & 10,1 & 10,2 & 10,5 \\
\hline SWE & 18,0 & 18,1 & 18,5 & 18,6 & 18,8 & 19,1 & 19,3 & 19,6 & 20,1 & 20,4 \\
\hline GBR & 116,6 & 116,9 & 117,5 & 118,8 & 120,2 & 123,0 & 125,1 & 127,0 & 128,2 & 129,8 \\
\hline ISL & 0,7 & 0,6 & 0,7 & 0,7 & 0,7 & 0,7 & 0,7 & 0,8 & 0,8 & 0,8 \\
\hline NOR & 10,0 & 10,0 & 10,1 & 10,3 & 10,4 & 10,5 & 10,5 & 10,6 & 10,7 & 10,9 \\
\hline $\mathrm{CHE}$ & 17,1 & 16,8 & 17,2 & 17,4 & 17,6 & 17,9 & 18,2 & 18,4 & 18,5 & 18,7 \\
\hline UKR & 33,2 & 33,9 & 34,0 & 34,1 & 34,2 & 31,0 & 31,9 & 31,7 & 31,5 & 31,5 \\
\hline
\end{tabular}

Source: compiled by the author, taking into account annual data from [5; 8]

$G D P$ - gross domestic product in cash equivalent;

$P$-number of employed (economically active) population, people;

$V$ - number of deaths in road accidents;

$i_{\text {safety }}$ - safety index which amounts to 5.55 .

Safety index is a stable indicator, which in general characterizes the overall level of development of the country and averages all the necessary calculations to determine the amount of socio-economic losses according to the formula (1). The authors assume that the safety index for the countries of the European Union should be higher but within the framework of this study - for compatibility of indicators - a single value of the safety index for all countries will be used.

2 Forecasting the amount of socio-economic losses caused by road accidents

To make a forecast of the amount of socio-economic losses caused by road accidents by 2025 , the method of extrapolation of trends will be used to determine the trends based on the dynamic series, taking into account the patterns that have developed in the past.

The following will reflect the mathematical apparatus for forecasting, the impact of the coronavirus epidemic, based on one of the EU 
Table 3

Number of deaths in road accidents for countries of the European Union and Ukraine from 2009 to 2018

\begin{tabular}{|c|c|c|c|c|c|c|c|c|c|c|}
\hline \multirow{2}{*}{ Country* } & \multicolumn{10}{|c|}{ Thousands persons } \\
\hline & 2009 & 2010 & 2011 & 2012 & 2013 & 2014 & 2015 & 2016 & 2017 & 2018 \\
\hline BEL & 0,94 & 0,85 & 0,86 & 0,77 & 0,76 & 0,75 & 0,76 & 0,67 & 0,61 & 0,60 \\
\hline BGR & 0,90 & 0,78 & 0,66 & 0,60 & 0,60 & 0,66 & 0,71 & 0,71 & 0,68 & 0,61 \\
\hline CZE & 0,90 & 0,80 & 0,77 & 0,74 & 0,65 & 0,69 & 0,73 & 0,61 & 0,58 & 0,66 \\
\hline DNK & 0,30 & 0,26 & 0,22 & 0,17 & 0,19 & 0,18 & 0,18 & 0,21 & 0,18 & 0,17 \\
\hline DEU & 4,15 & 3,65 & 4,01 & 3,60 & 3,34 & 3,38 & 3,46 & 3,21 & 3,18 & 3,28 \\
\hline EST & 0,10 & 0,08 & 0,10 & 0,09 & 0,08 & 0,08 & 0,07 & 0,07 & 0,05 & 0,07 \\
\hline IRL & 0,24 & 0,21 & 0,19 & 0,16 & 0,19 & 0,19 & 0,16 & 0,18 & 0,16 & 0,14 \\
\hline GRC & 1,46 & 1,26 & 1,14 & 0,99 & 0,88 & 0,80 & 0,79 & 0,82 & 0,73 & 0,70 \\
\hline ESP & 2,69 & 2,44 & 2,04 & 1,89 & 1,67 & 1,68 & 1,69 & 1,81 & 1,83 & 1,81 \\
\hline FRA & 4,27 & 3,99 & 3,96 & 3,65 & 3,27 & 3,38 & 3,46 & 3,47 & 3,44 & 3,25 \\
\hline HRV & 0,55 & 0,43 & 0,42 & 0,39 & 0,37 & 0,31 & 0,35 & 0,31 & 0,33 & 0,32 \\
\hline ITA & 4,24 & 4,11 & 3,86 & 3,75 & 40 & 3,38 & 3,43 & 3,28 & 38 & 33 \\
\hline CYP & 0,07 & 0,06 & 0,07 & 0,05 & 0,04 & 0,05 & 0,06 & 0,05 & 0,05 & 0,05 \\
\hline LVA & 0,25 & 0,22 & 0,18 & 0,18 & 0,18 & 0,21 & 0,19 & 0,16 & 0,14 & 0,15 \\
\hline LTU & 0,37 & 0,30 & 0,30 & 0,30 & 0,26 & 0,27 & 0,24 & 0,19 & 0,19 & 0,17 \\
\hline LUX & 0,05 & 0,03 & 0,03 & 0,03 & 0,05 & 0,04 & 0,04 & 0,03 & 0,03 & 0,04 \\
\hline HUN & 0,82 & 0,74 & 0,64 & 0,61 & 0,59 & 0,63 & 0,64 & 0,61 & 0,63 & 0,63 \\
\hline MLT & 0,02 & 0,01 & 0,02 & 0,01 & 0,02 & 0,01 & 0,01 & 0,02 & 0,02 & 0,02 \\
\hline NLD & 0,64 & 0,54 & 0,55 & 0,56 & 0,48 & 0,48 & 0,53 & 0,53 & 0,54 & 0,60 \\
\hline AUT & 0,63 & 0,55 & 0,52 & 0,53 & 0,46 & 0,43 & 0,48 & 0,43 & 0,41 & 0,41 \\
\hline $\mathrm{POL}$ & 4,57 & 3,91 & 4,19 & 3,57 & 3,36 & 3,20 & 2,94 & 3,03 & 2,83 & 2,86 \\
\hline PRT & 0,82 & 0,94 & 0,89 & 0,72 & 0,64 & 0,64 & 0,59 & 0,56 & 0,60 & 0,70 \\
\hline ROU & 2,80 & 2,38 & 2,02 & 2,04 & 1,86 & 1,82 & 1,89 & 1,91 & 1,95 & 1,87 \\
\hline SVN & 0,17 & 0,14 & 0,14 & 0,13 & 0,13 & 0,11 & 0,12 & 0,13 & 0,10 & 0,09 \\
\hline SVK & 0,38 & 0,37 & 0,33 & 0,35 & 0,25 & 0,30 & 0,31 & 0,28 & 0,28 & 0,26 \\
\hline FIN & 0,28 & 0,27 & 0,29 & 0,26 & 0,26 & 0,23 & 0,27 & 0,26 & 0,24 & 0,24 \\
\hline SWE & 0,36 & 0,27 & 0,32 & 0,29 & 0,26 & 0,27 & 0,26 & 0,27 & 0,25 & 0,32 \\
\hline GBR & 2,34 & 1,91 & 1,96 & 1,80 & 1,77 & 1,85 & 1,80 & 1,86 & 1,86 & 1,84 \\
\hline ISL & 0,02 & 0,01 & 0,01 & 0,01 & 0,02 & 0,00 & 0,02 & 0,02 & 0,02 & 0,02 \\
\hline NOR & 0,21 & 0,21 & 0,17 & 0,15 & 0,19 & 0,15 & 0,12 & 0,14 & 0,11 & 0,11 \\
\hline $\mathrm{CHE}$ & 0,35 & 0,33 & 0,32 & 0,34 & 0,27 & 0,24 & 0,25 & 0,22 & 0,23 & 0,23 \\
\hline UKR & 5,35 & 4,71 & 4,83 & 5,09 & 4,73 & 4,43 & 4,00 & 3,41 & 3,43 & 3,35 \\
\hline
\end{tabular}

Source: compiled by the author, taking into account annual data from [9]

countries is calculated and the overall forecast of the amount of socio-economic losses from road accidents is reflected.

2.1 Mathematical apparatus for forecasting by trend extrapolation method

The method of extrapolation of trends for forecasting is chosen according to the nature and volume of the initial data. In general, according to [11], the equation of the trend, which reflects the trend of the phenomenon change (process, object) in time, is calculated by formula (2):

$$
y=f(t)+\xi_{t}
$$

$f(t)$ - deterministic non-random component of the process;

$\xi_{t}$-stochastic random component of the process.

Equation of the trend for a particular task can be represented by different dependencies, in particular: linear, quadratic, power, exponential, exponential-step equivalent, and the like. For the purposes of this study, we chose the quadratic dependence to describe the equation of the trend.

The quadratic dependence of the equation of the trend for this study will be represented by formula (3): 


$$
y=a_{0}+a_{1} t+a_{2} t^{2}
$$

$a_{0}-$ the last initial value from which forecasting begins;

$a_{1}, a_{2}$ - parameters of the quadratic equation, \%;

$t$ - ordinal number of years.

Equation parameters $\left(a_{1}, a_{2}\right)$ will be determined by determinant method as a system of equations according to formula (4):

$$
\left\{\begin{array}{l}
\mathrm{a}_{1}=\frac{\sum \mathrm{y}_{\mathrm{t}} \sum \mathrm{t}^{2}-\sum \mathrm{ty}_{\mathrm{t}} \sum \mathrm{t}}{\mathrm{n} \sum \mathrm{t}^{2}-\left(\sum \mathrm{t}\right)^{2}} \\
\mathrm{a}_{2}=\frac{\mathrm{n} \sum \mathrm{ty} \mathrm{t}_{\mathrm{t}}-\sum \mathrm{t} \sum \mathrm{y}_{\mathrm{t}}}{\mathrm{n} \sum \mathrm{t}^{2}-\left(\sum \mathrm{t}\right)^{2}}
\end{array}\right.
$$

To assess the reliability of the calculated forecast, we will use the methodology of relative comparison of the deviations of actual values from the forecast calculated for the indicator of the first value in the range of actual values. For the purposes of this study, an error limit of $\pm 10 \%$ is accepted.

2.2 Impact of the Coronavirus epidemic (on example of forecasting Germany's GDP until 2025)

To calculate the forecast indicators of GDP it is necessary to calculate the parameters of the quadratic equation, make a forecast to assess the reliability of the forecast indicators and cal- culate the forecast values. To simplify the calculations, let us compile Table 4.

The arithmetical mean of the relative deviations of the actual values from the forecast ones obtained by the formulas (3-4) makes $\approx 6.0 \%$, the minimum deviation makes $(+2.0 \%)$, and the maximum deviation makes $(+9.9 \%)$, which meets the conditions of the maximum amount (10\%) of the error of calculations. Thus, there is an acceptable quality of forecasting indicators for predicting the amount of socio-economic losses caused by road accidents.

Given the economic consequences of the Coronavirus epidemic, the main wave of which took place in 2020, to calculate the amount of GDP, it is reasonable to take into account the average coefficient, which will take into account the difference between the forecast indicator of GDP, which is provided [7], and the estimated forecast according to Table 4.

So, the German GDP forecast for 2020 given in [7] is €3,330.23 billion. According to Table 5, the projected (estimated) GDP is €3,780.7 billion. Thus, for a correct forecast, it is advisable to take into account the correction factor, which will reflect the impact of the Coronavirus epidemic when calculating the GDP amount:

$$
\mathrm{K}_{\text {covid }}=(1-3780,7 \div 3330,23) \cdot 100=0,865
$$

\begin{tabular}{|c|c|c|c|c|c|c|c|}
\hline Year & $\begin{array}{c}\text { Actual } \\
\text { value } \\
\text { of GDP, } \\
\text { billion } \\
\text { euro } \\
y_{t} \\
\end{array}$ & $\begin{array}{c}\begin{array}{c}\text { Ordinal } \\
\text { number of } \\
\text { the year }\end{array} \\
t\end{array}$ & $\begin{array}{c}\text { Initial } \\
\text { value } \\
\text { for the } \\
\text { forecast } \\
\quad a_{0} \\
\end{array}$ & $\begin{array}{c}\text { Initial } \\
\text { parameter } \\
\text { of the } \\
\text { equation, } \% \\
a_{1}\end{array}$ & $\begin{array}{c}\text { Second } \\
\text { parameter } \\
\text { of the } \\
\text { equation, \% } \\
a_{2}\end{array}$ & $\begin{array}{c}\text { Forecast } \\
\text { value } \\
\text { of GDP, } \\
\text { billion } \\
\text { euro }\end{array}$ & $\begin{array}{c}\text { Relative } \\
\text { deviation }\end{array}$ \\
\hline 2009 & 2445,7 & 1 & $\mathrm{X}$ & 23,555 & 0,984 & $X$ & $x$ \\
\hline 2010 & 2564,4 & 2 & 2445,7 & 23,555 & 0,984 & 2615,4 & $102 \%$ \\
\hline 2011 & 2693,6 & 3 & 2564,4 & 23,555 & 0,984 & 2773,1 & $103 \%$ \\
\hline 2012 & 2745,3 & 4 & 2693,6 & 23,555 & 0,984 & 2855,3 & $104 \%$ \\
\hline 2013 & 2811,4 & 5 & 2745,3 & 23,555 & 0,984 & 2953,7 & $105 \%$ \\
\hline 2014 & 2927,4 & 6 & 2811,4 & 23,555 & 0,984 & 3104,2 & $106 \%$ \\
\hline 2015 & 3026,2 & 7 & 2927,4 & 23,555 & 0,984 & 3239,3 & $107 \%$ \\
\hline 2016 & 3134,7 & 8 & 3026,2 & 23,555 & 0,984 & 3386,1 & $108 \%$ \\
\hline 2017 & 3259,9 & 9 & 3134,7 & 23,555 & 0,984 & 3551,5 & $109 \%$ \\
\hline 2018 & 3356,4 & 10 & 3259,9 & 23,555 & 0,984 & 3690,3 & $110 \%$ \\
\hline 2019 & - & 11 & 3356,4 & 23,555 & 0,984 & 3734,5 & $X$ \\
\hline 2020 & - & 12 & 3356,4 & 23,555 & 0,984 & 3780,7 & $x$ \\
\hline 2021 & - & 13 & 3356,4 & 23,555 & 0,984 & 3828,9 & $X$ \\
\hline 2022 & - & 14 & 3356,4 & 23,555 & 0,984 & 3879,0 & $x$ \\
\hline 2023 & - & 15 & 3356,4 & 23,555 & 0,984 & 3931,0 & $x$ \\
\hline 2024 & - & 16 & 3356,4 & 23,555 & 0,984 & 3985,1 & $X$ \\
\hline 2025 & - & 17 & 3356,4 & 23,555 & 0,984 & 4041,1 & $X$ \\
\hline
\end{tabular}

Forecasting of GDP

Table 4 
2.3 Calculation of the predicted amount of socio-economic losses caused by road accidents

Using the input data given in Tables 1-3, the mathematical apparatus for forecasting outlined in Section 2.1 and formula (1), we calculated the forecast indicators of the amount of socio-economic losses caused by road accidents, which are shown in Table 5.

According to the results of calculations, we obtain the forecast value of socio-economic losses caused by road accidents for the countries of the European Union for the years 2021-2025 in the amount of $€ 343.3$ billions
(Figure 1). The countries with developed economies, high GDP per capita and a large number of fatalities in road accidents are at risk of the greatest losses - France, Germany, Italy and the UK.

3 Determination of the effectiveness of measures to improve road safety

Taking into account the fact that in Ukraine since 2018 the State program to improve road safety in Ukraine for the period up to 2020 [12] is in force, we will estimate the approximate socio-economic losses caused by road accidents for the period 2018-2020. The results of the calculation are presented in Table 6.

Forecast socio-economic losses caused by road accidents in Europe and Ukraine for 2019-2025

\begin{tabular}{|c|c|c|c|c|c|c|c|c|}
\hline \multirow{2}{*}{ Country } & \multicolumn{8}{|c|}{ Losses, billion Euro } \\
\hline & 2019 & 2020 & 2021 & 2022 & 2023 & 2024 & 2025 & $\Sigma$ \\
\hline Belgium & 2,825 & 2,453 & 2,462 & 2,469 & 2,474 & 2,478 & 2,479 & 17,641 \\
\hline Bulgaria & 0,486 & 0,425 & 0,429 & 0,434 & 0,438 & 0,443 & 0,448 & 3,102 \\
\hline Czechia & 1,260 & 1,094 & 1,099 & 1,103 & 1,106 & 1,109 & 1,111 & 7,880 \\
\hline Denmark & 0,873 & 0,757 & 0,759 & 0,760 & 0,760 & 0,760 & 0,759 & 5,429 \\
\hline Germany & 12,212 & 10,638 & 10,715 & 10,789 & 10,861 & 10,931 & 10,999 & 77,145 \\
\hline Estonia & 0,128 & 0,111 & 0,111 & 0,112 & 0,112 & 0,112 & 0,112 & 0,798 \\
\hline Ireland & 1,047 & 0,913 & 0,919 & 0,925 & 0,931 & 0,937 & 0,942 & 6,615 \\
\hline Greece & 1,365 & 1,170 & 1,157 & 1,141 & 1,122 & 1,100 & 1,076 & 8,130 \\
\hline Spain & 5,380 & 4,669 & 4,683 & 4,694 & 4,702 & 4,706 & 4,707 & 33,541 \\
\hline France & 13,336 & 11,610 & 11,685 & 11,757 & 11,825 & 11,889 & 11,949 & 84,051 \\
\hline Croatia & 0,486 & 0,421 & 0,421 & 0,421 & 0,421 & 0,420 & 0,419 & 3,010 \\
\hline Italy & 11,790 & 10,255 & 10,312 & 10,365 & 10,413 & 10,458 & 10,498 & 74,091 \\
\hline Cyprus & 0,121 & 0,105 & 0,105 & 0,105 & 0,106 & 0,106 & 0,106 & 0,754 \\
\hline Latvia & 0,233 & 0,203 & 0,204 & 0,205 & 0,205 & 0,206 & 0,206 & 1,462 \\
\hline Lithuania & 0,282 & 0,244 & 0,244 & 0,243 & 0,241 & 0,239 & 0,237 & 1,730 \\
\hline Luxembourg & 0,402 & 0,350 & 0,352 & 0,355 & 0,357 & 0,359 & 0,361 & 2,537 \\
\hline Hungary & 0,947 & 0,824 & 0,829 & 0,833 & 0,838 & 0,842 & 0,846 & 5,959 \\
\hline Malta & 0,048 & 0,042 & 0,043 & 0,044 & 0,044 & 0,045 & 0,046 & 0,312 \\
\hline Netherlands & 2,480 & 2,163 & 2,183 & 2,203 & 2,223 & 2,243 & 2,264 & 15,758 \\
\hline Austria & 1,782 & 1,548 & 1,554 & 1,559 & 1,562 & 1,565 & 1,567 & 11,137 \\
\hline Poland & 4,255 & 3,692 & 3,702 & 3,709 & 3,713 & 3,713 & 3,711 & 26,493 \\
\hline Portugal & 1,428 & 1,239 & 1,242 & 1,245 & 1,247 & 1,249 & 1,249 & 8,899 \\
\hline Romania & 2,140 & 1,866 & 1,882 & 1,899 & 1,915 & 1,931 & 1,947 & 13,580 \\
\hline Slovenia & 0,203 & 0,176 & 0,176 & 0,176 & 0,176 & 0,176 & 0,176 & 1,260 \\
\hline Slovakia & 0,450 & 0,391 & 0,393 & 0,394 & 0,396 & 0,396 & 0,397 & 2,818 \\
\hline Finland & 1,065 & 0,929 & 0,937 & 0,946 & 0,954 & 0,962 & 0,970 & 6,762 \\
\hline Sweden & 1,480 & 1,290 & 1,302 & 1,313 & 1,324 & 1,335 & 1,347 & 9,390 \\
\hline U.Kingdom & 6,878 & 6,005 & 6,063 & 6,121 & 6,180 & 6,239 & 6,298 & 43,784 \\
\hline Iceland & 0,099 & 0,087 & 0,088 & 0,090 & 0,092 & 0,094 & 0,096 & 0,646 \\
\hline Norway & 0,724 & 0,623 & 0,619 & 0,614 & 0,608 & 0,601 & 0,592 & 4,382 \\
\hline Switzerland & 1,540 & 1,337 & 1,341 & 1,344 & 1,346 & 1,347 & 1,346 & 9,600 \\
\hline Ukraine & 2,516 & 2,184 & 2,190 & 2,194 & 2,196 & 2,196 & 2,194 & 15,669 \\
\hline$\Sigma$ & 80,259 & 69,814 & 70,202 & 70,561 & 70,889 & 71,187 & 71,452 & 504,364 \\
\hline
\end{tabular}




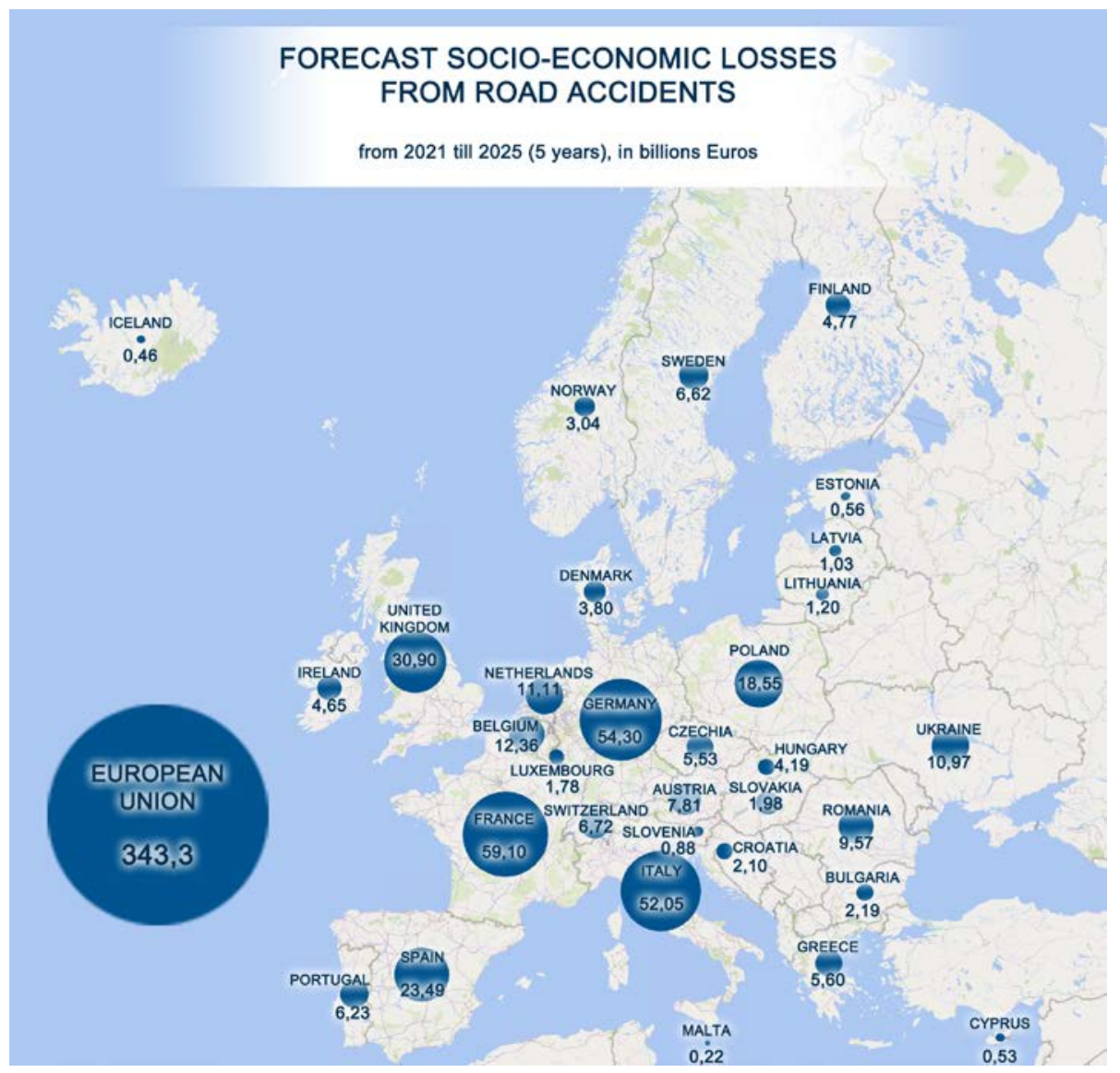

Figure 1. Forecast socio-economic losses from road accidents

Table 6

Effectiveness of measures to improve road safety in Ukraine

\begin{tabular}{|c|c|c|}
\hline Year & $\begin{array}{c}\text { Funding } \\
\text { of measures } \\
\text { to improve safety, } \\
\text { million euros }\end{array}$ & $\begin{array}{c}\text { Forecast } \\
\text { of losses from } \\
\text { road accidents, } \\
\text { million euros }\end{array}$ \\
\hline 2018 & 28,61 & 2268,85 \\
\hline 2019 & 94,91 & 2515,91 \\
\hline 2020 & 112,68 & 2183,54 \\
\hline
\end{tabular}

Therefore, the allocation of $€ 236.2$ million during 2018-2020 resulted in a significant reduction in socio-economic losses from road accidents by $€ 332,4$ million. This demonstrates the economic efficiency of similar public investments in the amount of $40.7 \%$, which proves the high economic efficiency of financing this direction.
Conclusions. Calculating the amount of socio-economic losses by road accidents allows indicate efficient use of budgetary financial resources for other needs.

Taking into account different levels of economic development, different set of indicators forming the socio-economic losses from road accidents, different levels of budget financing, different approaches and a list of technological operations when performing road works, we can assume that the effectiveness of measures aimed at improving the road safety in the leading European countries is in the range of $20-30 \%$.

Based on this, the level of national income growth of the European Union countries due to the reduction in the number and consequences of road accidents is estimated in the amount of savings from 69 to 103 billion Euro in the 5-year perspective.

\section{REFERENCES:}

1. Bezuglyi A. (2013) Otsinka socialno-economichnykh vtrat vid dorozhnyo-transportnykh prygod [Assessment of the socio-economic costs of road accidents]. Management of project, systems analysis and logistics, no. 12, pp. 231-238. (in Ukrainian)

2. Bezuglyi A., Kontseva V., Stasiuk B. (2019) The Theorethical Aspects of Determination Index of Socio-economic Losses from Road Accidents. Visnyk National Transport University, issue 2(44). 
3. Bezuglyi A., Kontseva V., Stasiuk B. (2020) The Conceptual Background of Determination and the Reasoning of Size of Socio-Economic Losses from Road Accidents. Dorogi i mosti [Roads and bridges], no. 21, pp. 18-27. Available at: http://dorogimosti.org.ua/files/upload/18-27.pdf

4. Stasiuk B., Bezuglyi A., Kontseva V. (2020) The Rationale of the Safety Index for Estimation of Socio-Economic Costs of Road Accidents, Rivista Di Studi Sulla Sostenibilita, Issue 2.

5. Statistic of population and employment and GDP in Ukraine. Available at: http://www.ukrstat.gov.ua/ (accessed 07 February 2021).

6. Official exchange rates from Euro to Hryvna. Available at: https://bank.gov.ua/ua/markets/exchangeratechart?startDate=01.01.2009\&endDate=14.02.2021 (accessed 07 February 2021).

7. Statistic of GDP and main components (output, expenditure and income) in Europe. Available at: https://ec.europa.eu/eurostat/databrowser/view/NAMQ_10_GDP_custom_542678/default/table?lang=en (accessed 07 February 2021).

8. Statistic of population and employment in Europe. Available at: https://ec.europa.eu/eurostat/databrowser/ view/NAMQ_10_PE_custom_542660/default/table?lang=en (accessed 07 February 2021).

9. Statistic of persons killed in road accidents by type of vehicle (CARE data) in Europe. Available at: https://appsso.eurostat.ec.europa.eu/nui/show.do?dataset=tran_sf_roadve\&lang=en (accessed 07 February 2021).

10. Bezuglyi A., Bibyk Y., Stasiuk B.: M 42.1-37641918-779:2020 "Methodology estimation socio-economic costs of road accidents", signed first deputy of Head of State Road Agency of Ukraine.

11. Graboveckyi B. (2013) Plannuvannia ta Economichne Prognozuvannia [Planning and economic forecasting], Second edition, VNTU. Available at: http://hrabovecky.vk.vntu.edu.ua/file/b62a24a7998a0cfba91c11ba7ec693df.pdf

12. Resolution of the Cabinet of Ministers of Ukraine Pro zatverdzhennya Derzhavnoyi prohramy pidvyshchennya rivnya bezpeky dorozhn'oho rukhu v Ukrayini na period do 2020 roku [About Approval of the State Program to Increase the Level of Road Safety in Ukraine for the Period up to 2020]. Available at: https://zakon.rada.gov.ua/laws/ show/435-2018-\%D0\%BF\#Text (accessed 07 February 2021). 